\title{
Determinants of the Return Migration of Household Heads from South Eastern Zimbabwe to South Africa During Prolonged Crisis, 2000-16
}

\author{
Dick Ranga \\ Department of Development Studies, Faculty of Applied Social Sciences, Zimbabwe Open University - \\ Manical-and Regional Campus, Mutare, Zimbabwe \\ rangadic@yahoo.com
}

\begin{abstract}
The study assessed return migration by heads of households that migrated during the prolonged crisis, 2000-16. It collected data among 166 households from four districts in South Eastern Zimbabwe. Most of the male household heads had previously migrated, half of them to South Africa. Non-migrant heads were mainly females who remained behind when their husbands migrated to South Africa or urban areas. Both heads who returned from migrating to South Africa and locally to urban areas came back during 2011-15 with the desire to reunite with families. This period was associated with severe retrenchments by Zimbabwean companies that attempted to survive the shrinking economy. Yet it was also an attractive period to return home for international migrants because of the stability brought by the adoption of multiple currencies. Xenophobic attacks in South Africa in 2015 also 'pushed' some of the heads into returning home. International return migrants were significantly younger and had lower levels of education than internal and non-migrants. Three-tenths of them returned into households having traditional huts as their main houses which suggested that migration was unsuccessful for them. There is a need for restoration of stability soon after a crisis since this helps attract back human capital.
\end{abstract}

Keywords: Migration; Return migrants; Zimbabwean crisis; Southeastern Zimbabwe; migration to South Africa

\section{Introduction}

There is a long history of migration from Zimbabwe especially from the southern districts to South Africa. Crush (2002) probably referred to southern Zimbabwe when he argued that "almost a quarter of adult Zimbabweans have parents and grandparents who have worked in South Africa at some point in their lives". Muzondidya (2008) classified Zimbabwean immigrants in South Africa into 'earlier' and 'recent' migrants. Among other groups, earlier migrants included unskilled and semi-skilled Zimbabweans who together with Zambians, Malawians and Mozambicans migrated or were forced into migration to work in South African mines or commercial farms during colonialism. This author also included among the earlier migrants those young single men from southern Zimbabwe who migrated to South Africa in the late 1980s and 1990s after seeing signs of trouble in the Zimbabwean economy (Muzondidya, 2008). Concurring, Manamere (2014:92) argued that "many young rural men in Southern Mozambique and Zimbabwe came to see their movement across the border as a necessary 'rite of passage', and step to marriage and social adulthood". On the other hand, recent migrants included several hundred thousands of Zimbabweans who escaped the political and economic crisis in Zimbabwe after 2000. This crisis 'pushed' into migration Zimbabweans of all walks of life including both the young and old, married and single, southerners and northerners, skilled and unskilled (Muzondidya, 2008). Pasura (2008) estimated the number of Zimbabweans who left the country at about 3 to 4 million, which warranted use of the term 'mass exodus.

According to the UNDP (2010), about 83\% of them migrated to destination countries in Africa especially neighboring countries like South Africa, Botswana, Malawi, Namibia, Zambia, and Mozambique. Two-thirds of them were living in South Africa (UNDP, 2010). This was due to Zimbabwe's proximity to South Africa and Botswana where there are economic stability and better wages and employment standards (Crush and Tevera, 2010; Lefko-Everett, 2004). Both skilled and unskilled Zimbabweans were also in demand in these countries. The political crisis involved inability by government to curb corruption involving some of its members, prioritizing some political and autocratic decisions at the expense of the economy, the violent 'fasttrack' land reform program, resorting to violence in order to suppress the opposition, and disputes related to election results and the rule of law (Murisa, 2010). On the other hand, the economic crisis started when the government adopted the market-based development program dubbed the Economic Structural Adjustment Program (ESAP) in 1991-95. Instead of improving investments and relocating labor efficiently according to 
neo-liberal economics, ESAP resulted in "de-industrialization, growing unemployment and the severe erosion of living standards of the majority" (Mlambo and Raftopoulos, 2010:2).

The situation worsened after the 2000s with more companies downsizing or closing down operations in response to the political crisis. To exacerbate the situation, inflation rose to unprecedented levels such that by July 2008 it reached a record 231 million percent (Chagonda, 2010). The study assessed the determinants of returning home by heads of households that migrated to South Africa during the prolonged crisis. In other words, it explained what made some heads of households from south-eastern Zimbabwe return home while others remained in diaspora especially in South Africa. There is a belief that many of the men who migrate from this region to South Africa neglect their families left back home while they start new families in South Africa. This study hopes to allay this belief explaining how factors like personal, household and district level characteristics increased the tendency by some migrant heads of households to return home. It also placed their return in context citing how events such as the restoration of economic stability by the GNU in Zimbabwe and xenophobic attacks in South Africa 'pulled' or 'pushed' some of the heads of households into returning home. By studying return migration of household heads in their places of origin, the study was different from others which focused on the host country like South Africa studying those with intentions to return home (but may never have returned). It also had the chance of capturing return migration from other destinations both in Zimbabwe (internal migration) and other countries besides South Africa. It answered the often unanswered questions: have some of the Zimbabweans who escaped to South Africa during the crisis returned home? If yes, what factors determined their returning home? This is important for policymakers as they can manipulate those factors which increase the return migration of previously lost human resources.

\section{The Objectives of this Study Included to:}

- Analyze the level of return migration by household heads in southeastern Zimbabwe.

- Explore the reasons for returning home by household heads in southeastern Zimbabwe.

- Assess for associations between the personal characteristics of the household heads and their migration status.

- Determine the role played by household and district level variables in the return migration of household heads in southeastern Zimbabwe.

\section{Literature Review}

One of the few studies on return migration of Zimbabweans from South Africa was conducted by Makina (2012) and based on the migrants' future intentions. He found that $47 \%$ of the migrants who left for purely economic reasons or $34 \%$ for political reasons "were more likely to return than those who left for other reasons or for a combination of political and economic reasons" (Makina, 2012:369). Studies conducted by Crush and others found that $67 \%$ of Zimbabweans based in the United Kingdom and $65 \%$ of those in South Africa were likely to return at some time in the future (Mandiyanike, 2014). The decision to return home by most of the Zimbabweans in South Africa depended on the restoration of stability in the country (Makina, 2012). There is evidence that economic stability somehow returned and social service delivery improved after the Government of National Unity (GNU) officially adopted multiple currencies dominated by the United States (US) dollar in February 2009. For instance, one year later, the International Crisis Group "observed that the unity government was clearly making discernible, albeit sometimes painfully slow, progress in a number of areas" (Mandiyanike, 2014:5). Such areas included the reopening of schools and hospitals; the payment of civil service workers in foreign currency even though they were started with allowances of US $\$ 100$ across the board; increased availability of goods in the supermarkets; and control of the cholera epidemic.

The adoption of multiple currencies automatically reduced inflation and contributed to the first positive growth of the economy in a decade of 4.7 per cent in 2009 (Mandiyanike, 2014). Although the political situation remained uncertain, these positive changes in the economy and social service delivery were likely to influence some Zimbabwean migrants into returning home. This is consistent with the structuralist theory of migration which states that the decision to return home is often affected by situational and structural factors. According to this theory, the migrant is likely to return home after taking into consideration the reality of the socio-economic situation in the home country vis-à-vis his/her expectations for successful return migration 
(Makina, 2012). This theory is relevant given that we are in the age of information technology such that immigrants can easily become aware of the social, economic and political changes taking place in the home country. Based on this argument, Makina (2012) argued that those Zimbabwean migrants who left after the 2000 political and economic crisis were more likely to return than those who left before the crisis.

Studies conducted by Crush and others suggested that a counter-flow of migrants was likely to occur in crisis driven situations such as that of Zimbabwe once the crisis conditions were resolved (Mandiyanike, 2014). This is analogous to other political crises like war whereby the refugees would return home when a preferred political system is in place (Makina, 2012). Returning home was likely to be determined by several factors including personal characteristics of the return migrant such as age, marital status and education and household factors such as a number of dependents (or household size), ownership of cattle, and others. Roman and Goschin (2014) cited several factors related to the host country, which may act as 'push' factors for professional migrants particularly health workers to return home. These include being ill-treated or discriminated against as outsiders. This was relevant in the case of Zimbabweans' return from South Africa since the nationals of other African countries were subjected to xenophobic attacks in South Africa in 2008 and 2015. They were accused of taking jobs that belong to South Africans and lowering wages since in their desperation to survive they would accept low wages. Some immigrants including Zimbabweans have been seriously injured or lost their lives in these attacks (New Zimbabwe, 15 April 2015). This was likely to be one of the reasons for returning home by household heads in southeastern Zimbabwe. Other migrants might return due to social reasons particularly those related to migration and the family setup.

Those migrants who relocate alone leaving the spouse and children behind are likely to return home even when the wage differentials are not in favor of returning in order to reunite with their families. This has led some scholars to include spousal separation as a determinant of return migration (Makina, 2012). According to neoclassical economic theory migration is caused by economic factors particularly the wage difference between the sending country and the receiving country. For return migration to occur, the wages in the home country should be higher than those paid in the host country. Migrants might return home even when there are non-monetary gains for returning including the chance to use one's skills and knowledge gained while abroad. For instance, Makina (2012) argued that the probability to return was higher for skilled migrants as their chances of finding employment at home were stronger. This probability, however, got lower as the income level of the immigrant got higher. The new household economics theory of migration highlighted that migration decisions are not only made by calculating individuals but also by "larger units of related people" such as the family or household in order to maximize expected income or minimize risk against uncertainties in life (Massey et al., 1993:436). Such uncertainties include crop failures related to droughts which are more frequent nowadays due to climate change, imperfect markets, and unemployment. This theory is related to the argument that some migrants move in order to raise income for starting a business at home. In this case, return migration is likely to occur when the migrant has started a business at home through which he/she can reduce other risks including crop failure, imperfect crop markets or unemployment.

\section{Methodology}

The study mainly adopted a design in migration studies whereby the migrants' wives and other family members left behind provided information on behalf of the absent migrants. Although the remaining family may not be exactly aware of why the migrant left, there are advantages associated with this design such as the chance to interview those migrants who have returned home. Four districts in southeastern Zimbabwe including Zaka, Bikita, Chipinge and Chimanimani were purposively selected. These districts were targeted since they have a long history of sending labor migrants to South Africa. This made identifying households with heads that have migrated to South Africa but have since returned home easier. In each of the four districts, two Wards in close proximity to each other were selected purposively in order to reduce the travelling expenses that would be incurred if the two Wards were far apart. The Wards included one with an urban Centre such as a growth point (pole) and another purely rural. This was meant to represent both rural and urban areas since Zimbabweans of all walks of life (rural and urban) migrated to South Africa during the crisis. Snowball (or referral) sampling was used to select households with labor migrants in South Africa. Although a non-probability sampling technique, snowball sampling allows the researcher to reach populations that are difficult to sample when using other sampling methods (Creswell, 2011). Moreso, the 
process is cheap, simple and cost-efficient. One hundred and sixty-six (166) households out of 200 households targeted, which indicated a response rate of $83 \%$, responded to the questionnaire. The lowest proportions came from Chipinge (39) and Chimanimani (30) districts where some households were afraid of disclosing the whereabouts of their members who had crossed the border clandestinely or mistook the research assistants for donors who might deny them aid given that they had members in the diaspora. Household heads were asked whether they migrated before, to where and when they returned.

This led to their classification into those who had migrated to another country (international return migrants), to a place in Zimbabwe (internal return migrants) and those who never migrated before (nonmigrants). Data analysis involved testing for associations between the head's migration status and their personal, household and district characteristics using the Pearson Chi-square. This helped reveal characteristics of the household heads which were significantly associated with international or internal return migration or non-migration. The Statistical Package for the Social Sciences (SPSS) software was used both for data entry and analysis. Data were presented in frequency tables and figures.

\section{Results and Discussion}

The Level of Return Migration into Households of Origin in South Eastern Zimbabwe: Table 1 shows that together about three-fifths (63.2\%) of the heads of households studied in southeastern Zimbabwe were returned migrants as they had previously migrated. While $52.4 \%$ of them had returned from migrating locally to other places in Zimbabwe (internal return migrants), $47.6 \%$ returned from migrating to another country (international return migrants). The majority (45 out 54 or $83.3 \%$ ) of the internal return migrants had returned from migration to urban areas in Zimbabwe. This was most probably due to challenges related to the prolonged crisis such as premature de-industrialization and retrenchments. An overwhelming majority (45 out 49 or $91.8 \%$ ) of the international return migrants returned from migrating to South Africa. This suggested that most of the household heads in these districts migrate to South Africa which confirmed other studies that argued that most Zimbabweans displaced by the crisis at home migrated to South Africa or Botswana (Crush and Tevera, 2010). This also confirmed the existence of a counter-stream of Zimbabweans from South Africa should stability return to Zimbabwe (Mandiyanike, 2014). The rest were non-migrants as they had never migrated before (Table 1). Most of them were likely to be females whose husbands had migrated to South Africa.

Table 1: Where Household Head Migrated to, When and Why Returned Home

\begin{tabular}{lll}
\hline Variable & No. & \% \\
\hline Where migrated before? & 60 & 36.8 \\
Non-migrant & 49 & 30.1 \\
International & 54 & 33.1 \\
Internal & 76 & 75.2 \\
Activity while in the host country/area & 13 & 12.9 \\
Working / looking for work & 9 & 8.9 \\
Studying & 3 & 3.0 \\
Married & & \\
Visiting & 13 & 14.0 \\
When returned home (N=93) & 12 & 12.9 \\
2005 or before & 44 & 47.3 \\
2006-2010 & 24 & 25.8 \\
2011-2015 & & \\
2016 & 41 & 41.8 \\
Why returned home & 12 & 12.2 \\
Reunite with family & 10 & 10.2 \\
A failure, had nothing & 4 & 4.1 \\
Xenophobia & 5 & 5.1 \\
Stability/peace in Zimbabwe & 14 & 14.3 \\
Started business & & \\
Acquired skills to use at home &
\end{tabular}




\begin{tabular}{lll}
\hline Weak currency in SA & 5 & 5.1 \\
To retire at home & 4 & 4.1 \\
Other & 3 & 3.0 \\
\hline
\end{tabular}

Source: Survey results

Three-quarters of the household heads that returned home were working or looking for work wherever they immigrated, indicating that they were labor or economic migrants (Table 1). This confirmed Kiwanuka and Monson (2009) who argued that most of the Zimbabweans who escaped the crisis were economic migrants rather than refugees where they immigrated. The largest proportion $(47.1 \%)$ of the household heads returned between 2011 and 2015 (Table 1). An assessment of the association between the period when returned and migration status revealed a significant result $(\mathrm{P}<0.05)$ which indicated that the majorities (51.1\% and $42.6 \%$, respectively) of both those who returned from migrating to South Africa and locally came back during this same period (2011-15).

For those who returned from migrating to South Africa, this was probably because of the improvement in the economy and social service delivery at home as a result of the GNU's adoption of multiple currencies dominated by the United States Dollar (Mandiyanike, 2014). Others could have been 'forced' to return home by the second major xenophobic attacks in South Africa in 2015. As for those who returned from migrating to other places in Zimbabwe, this was probably because of retrenchments as Zimbabwean companies tried to remain viable in the shrinking economy. For instance, the Southern Eye of 6 May 2015 cited the Zimbabwe National Statistics Agency (Zimstats) which estimated the number of employees retrenched between 2011 and 2014 at 227,000 .

The Household Heads' Reasons for Returning Home: The majority (41.8\%) of the heads who migrated before returned because they desired to reunite with families left back home (Table 1). This supported studies that emphasize the role played by family factors such as reunification in the decision to return home (Makina, 2012). The second largest proportion (14.3\%) of the household heads returned because they realized the opportunity to use the skills that they gained abroad at home. This confirmed Wilson's 1985 and Sjaastad's 1962 Human Capital models which argue that migrants return because they have acquired higher qualifications or skills while abroad which they hope to use at home. Other researchers found that more than half $(58 \%)$ of migrant Vietnamese in the Pacific desired to use knowledge gained abroad upon returning (Iredale, Guo and Rozario, 2003). This was followed by those who returned because their migration was "a failure; they had nothing" (12.2\%). This supported the neoclassical theory which explains return migration in terms of failure not only to find a job but one that pays more than those in the home country. Failure might also have meant that the migrant came back with nothing after having failed to remit meaningfully as argued by Hungwe (2012). Xenophobia 'forced' one-tenth of the household heads who migrated before to return home (Table 1).

As mentioned already, there were xenophobic attacks on Zimbabweans and immigrants from other African countries in South Africa sometime during 2008 and 2015 (New Zimbabwe, 15 April 2015). These foreigners were blamed by South Africans for taking their jobs as well as lowering wages as they accepted low wages for them and their families left in Zimbabwe to survive. While returning because of the desire to reunite with families left back home was associated with both those who migrated to South Africa and locally (53.2\% and $44.9 \%$, respectively), xenophobic attacks were mainly mentioned by those who migrated to South Africa. On the other hand, those who mainly mentioned having started a business at home or acquired skills which they intended to use at home were internal migrants who had migrated mainly to Zimbabwe's urban areas. This included rural teachers who had migrated to urban areas in order to study as teachers at the colleges and universities which are mainly found in towns and cities in Zimbabwe. 
Table 2: When and Why Returned by Migration Status of the Household Head

\begin{tabular}{lll}
\hline When and why returned home & $\begin{array}{l}\text { International } \\
\mathbf{\%}(\mathbf{N}=\mathbf{4 9})\end{array}$ & $\begin{array}{l}\text { Internal } \\
\mathbf{\%}(\mathbf{N}=\mathbf{5 4})\end{array}$ \\
\hline When returned home* & & \\
Before 2006 & 6.7 & 23.3 \\
$2006-2010$ & 6.7 & 19.1 \\
$2011-2015$ & 51.1 & 42.6 \\
2016 & 35.6 & 17.0 \\
Why returned home** & & \\
Reunite with family/Retired & 53.2 & 44.9 \\
A failure, had nothing & 12.8 & 10.2 \\
Xenophobia & 21.3 & 0.0 \\
Stability at home/weak currency & 6.4 & 12.2 \\
Started business/acquired skills & 6.4 & 32.7 \\
\hline
\end{tabular}

Source: Survey results

* Significant at $5 \%$ level $(\mathrm{P}<0.05) * *$ Significant at $1 \%$ level $(\mathrm{P}<0.01)$

Source: Survey results

The other reasons for returning mentioned by smaller proportions or numbers of the migrant heads included stability or peace in Zimbabwe, the desire to retire at home, weaker currency in the host country and others like illness (Table 1). This supported the notion that stability in the economy and improvements in social service delivery especially during the period of the GNU (2009-13) influenced some of them into returning home.

Personal Characteristics by Migration Status of the Household Head: A significant result $(\mathrm{P}<0.05)$ indicated an association between migration status and age of the household head. While the majority (58.3\%) of the non-migrant heads of households was aged 40 or older, the largest proportions of both those who migrated to South Africa (international) and locally (internal) were aged 30-39 $(49.0 \%$ and 50.0\%, respectively) (Table 3). In other words, non-migrants were significantly older than both groups of return migrants. Instead of returning in their old ages for retirement, most of the household heads came back early and in the middle of their family and working lives. This confirmed that their return migration was mainly 'pushed' or 'pulled' by circumstances in which they found themselves such as xenophobic attacks in South Africa or retrenchments in Zimbabwe's urban areas.

A highly significant result $(\mathrm{P}<0.01)$ indicated an association between migration status and sex of the household head. While three-fifth of the non-migrant heads of households were females the majorities (75.5\% and 59.3\%, respectively) of both heads that migrated to South Africa and locally were males (Table 3). There is gender inequality in labor migration from this region with female heads of households less likely to ever migrate especially to South Africa than their male counterparts. This confirmed that southeastern Zimbabwe is one of those regions in which labor migration is still a men's affair while women and children remain behind.

Table 3: Personal Characteristics by Migration Status of the Household Head

\begin{tabular}{llll}
\hline Characteristic & $\begin{array}{l}\text { Migration status } \\
\text { Non-migrant } \\
\text { \% (N=60) }\end{array}$ & $\begin{array}{l}\text { International } \\
\mathbf{\%}(\mathbf{N}=\mathbf{4 9})\end{array}$ & $\begin{array}{l}\text { Internal } \\
\mathbf{\%}(\mathbf{N}=\mathbf{5 4})\end{array}$ \\
\hline Age (years)* & & & \\
Below 30 & 15.0 & 20.4 & 20.4 \\
30-39 & 26.7 & 39.0 & 50.0 \\
40 or older & 58.3 & 30.6 & 29.6 \\
Sex & & & \\
Male & 40.0 & 75.5 & 59.3 \\
Female & 60.0 & 24.5 & 40.7 \\
Marital status & & & \\
\hline
\end{tabular}




\begin{tabular}{llll}
\hline Never married & 8.3 & 8.2 & 9.3 \\
Married & 68.3 & 75.5 & 79.6 \\
Disrupted & 23.3 & 16.3 & 11.1 \\
Highest education level** & & & \\
Not educated & 6.7 & 8.2 & 9.3 \\
Primary & 35.0 & 26.5 & 7.4 \\
Secondary & 55.0 & 51.0 & 57.4 \\
Certificate/Diploma/Degree & 3.3 & 14.3 & 25.9 \\
\end{tabular}

Source: Survey results

* Significant at $5 \%$ level $(\mathrm{P}<0.05)$ ** Significant at $1 \%$ level $(\mathrm{P}<0.01)$

This presents challenges to these women as found by other researchers since some of the migrant husbands may forget their families left behind and start new families in the host country (Muzondidya, 2008). This was particularly so because the migrants' wives left in Zimbabwe never visited them while in South Africa. This further places them at risk of being infected with sexually transmitted illnesses (STIs) such as HIV and AIDS by their spouses when they return home. A few studies have, however, highlighted the positive effects of this labor migration involving men including increased female autonomy (Yabiku, Agadjanian and Sevoyan, 2010). The result for marital status, which was statistically insignificant, indicated no differences in marital status among the non-migrants, international and internal return migrants as their majorities $(68.3 \%, 75.5 \%$ and $79.5 \%$, respectively) were married (Table 3). However, most of the household heads with disrupted marriages were found among the non-migrants (23.3\%). This suggested that not all of the female heads of household were heads because their husbands had migrated to South Africa (de facto) but a few were probably de jure heads of household due to widowhood, divorce or separation. A highly significant result $(\mathrm{P}<0.01)$ indicated an association between migration status and education level of the household head. The majorities $(55.0 \%, 51.0 \%$ and $57.0 \%$, respectively) of the non-migrants, international and internal return migrants had some secondary education since four years of secondary education is the norm in Zimbabwe. Major differences were found in the second largest proportions.

While the second majorities for non-migrants and those who returned from migrating to South Africa (35.0\% and $26.5 \%$, respectively) had primary education only, the second largest proportion $(25.9 \%)$ of those who returned from migrating locally (internal) was professionally qualified with a certificate or diploma or degree. In other words, there were more educated heads among those who returned from migrating locally than those who returned from South Africa or those who never migrated. This confirmed other studies which argue that some of the labor migrants from southeastern Zimbabwe migrate to South Africa soon after completing Grade 7 (Zimbabwe Youth Council, 2014; Manamere, 2014). This also confirmed that some of the heads migrated locally to urban centres in order to further their education.

Household and District Level Variables by Type of Return Migration: A significant result $(\mathrm{P}<0.05)$ also indicated an association between migration status of the household head and one of the indicators of socioeconomic status that is, materials used to build the main house. The majorities of non-migrants, international and internal return migrants $(84.5 \%, 70.8 \%$ and $88.9 \%$, respectively) had main houses built of brick walls and iron/asbestos/tile roofs. The proportion (70.8\%) for international return migrants was, however, the lowest (Table 4). On the other hand, nearly three-tenth of the international return migrants had traditional huts made of pole and dagga or brick walls and thatch as their main houses. This suggested that some international migrants to South Africa failed to improve their socio-economic statuses even after migrating to 'the land of gold' (egoli). This further supports our earlier finding that some of the heads who returned from South Africa were failures as they had nothing to show for their migration.

This confirmed Hungwe (2012) who said some migrants came back with nothing after having failed to remit meaningfully. Although the result for household size was insignificant, the distribution was slightly as expected since larger proportions $(53.5 \%$ and $64.4 \%$, respectively) of both international and internal return migrants came from smaller households (1-5 members) (Table 4). We expected heads from smaller households to return home than those from larger households who would continue working abroad in order 
to provide for the large households. Similarly, other scholars argued that migrants with more numbers of dependents are less likely to return than those with fewer dependents (Makina, 2012).

Table 4: Household and District Level Variables by Migration Status of the Head

\begin{tabular}{|c|c|c|c|}
\hline Variable & $\begin{array}{l}\text { Migration stat } \\
\text { Non-migrant } \\
\%(\mathrm{~N}=60)\end{array}$ & $\begin{array}{l}\text { International } \\
\%(\mathrm{~N}=49)\end{array}$ & $\begin{array}{l}\text { Internal } \\
\%(\mathrm{~N}=54)\end{array}$ \\
\hline \multicolumn{4}{|l|}{ Household size } \\
\hline 1-5 members & 45.6 & 53.5 & 64.4 \\
\hline 6 or more & 54.4 & 46.5 & 35.6 \\
\hline \multicolumn{4}{|l|}{ Materials used to build main house* } \\
\hline Mud/brick + thatch & 15.5 & 29.2 & 11.1 \\
\hline Brick + iron sheets/asbestos/tiles & 84.5 & 70.8 & 88.9 \\
\hline \multicolumn{4}{|l|}{ Ownership of cattle / plough } \\
\hline Own cattle/plough/both & 48.3 & 50.0 & 63.5 \\
\hline Neither own cattle nor plough & 51.7 & 50.0 & 36.5 \\
\hline \multicolumn{4}{|l|}{ District** } \\
\hline Chimanimani & 25.0 & 20.4 & 9.3 \\
\hline Chipinge & 26.7 & 26.5 & 16.7 \\
\hline Bikita & 16.7 & 20.4 & 50.0 \\
\hline Zaka & 31.7 & 32.7 & 24.1 \\
\hline
\end{tabular}

Source: Survey results

* Significant at $5 \%$ level $(\mathrm{P}<0.05){ }^{* *}$ Significant at $1 \%$ level $(\mathrm{P}<0.01)$

Another insignificant result was for the other variable assessing the socio-economic status of the household, whether owned cattle or plough. Almost equal proportions (half-half) of the non-migrant and international return migrants owned or did not own cattle, a plough or both. In contrast, a larger proportion (63.5\%) of the internal return migrants owned cattle, a plough or both. This suggested that some heads who returned from migrating locally (internal) were socio-economically better than those who returned from South Africa or those who never migrated as they owned cattle, a plough or both. A highly significant result $(\mathrm{P}<0.01)$ also showed an association between migration status of the household head and district.

Nearly one-third, the majority, of those who returned from migrating to South Africa came from Zaka district while the second majority (26.5\%) came from Chipinge district. This was probably because of the close proximity of Zaka to South Africa than Chipinge such that some of the migrants 'jump' the border through informal routes in the forests. Most of rural Zaka district, like Chiredzi, is also so dry that livelihoods based on small-scale rain-fed agriculture alone cannot be sustained. In contrast, half of the internal return migrants were found in Bikita district and the second majority (24.1\%) in Zaka district (Table 4). In other words, there were more household heads that returned from migrating locally than to South Africa from Bikita district. This confirmed that there was more labor migration from Bikita district to towns and cities in Zimbabwe than from the other districts. This was probably because of Bikita's location on the highway between Masvingo town and the city of Mutare in the east. Hence, other potential labor migrants from Bikita could have moved to either urban Centre than South Africa.

\section{Conclusion and Recommendations}

Most of the household heads who returned from migrating to another country had gone to South Africa while those who returned from migrating locally had gone to towns in Zimbabwe. Since most of the non-migrant heads were females, they were probably the wives of men that had migrated to South Africa. The study noted, however, that a few of them were actually de jure female heads of households. The majorities of both the international and internal return migrants came back home during 2011-15. For those who came from migrating locally to Zimbabwean towns, this was because companies were retrenching during this period in order to remain viable in the shrinking economy. As for the heads who returned from migrating to South Africa, this was because the Zimbabwean economy was more stable than when they left at the peak of the crisis (2007-09) due to the adoption of multiple currencies in February 2009 or because of xenophobic 
attacks in South Africa in 2015. However, the reason stated by most of the migrant heads for returning was the desire to reunite with families left back home. The other reasons were different with xenophobia mainly mentioned by those who returned from migrating to South Africa while "started a business or acquired skills to use at home" were reasons mainly mentioned by those who returned from migrating locally to urban areas.

Some of them could have migrated to towns to train as teachers where most of the teachers' colleges are found. Return migrants were exclusively male which was typical of labor migration in the past. They were significantly younger than non-migrants having returned in the middle of their active ages because of favorable conditions at home or unfavorable ones at destination areas including xenophobia or retrenchment. Slightly above a quarter of those who returned from migrating to South Africa were associated with low levels of education, which confirmed that some of them migrate to South Africa soon after completing Grade 7. As a result, three-tenth of them was relatively poor as they came from households having traditional huts as their main houses. This was despite having migrated to 'egoli' (land of gold). Furthermore, Zaka district was most associated with heads who returned from another country particularly South Africa probably because of its close proximity to that country. On the other hand, Bikita district was most associated with those who returned from migrating locally especially to urban areas in Zimbabwe.

\section{The Study Recommends that:}

- There is need to restore stability immediately after a crisis in developing countries since this helps attract back those nationals including heads of households who would have escaped the country during the crisis in order to help families survive.

- The government of Zimbabwe should control migration of young men from south-eastern Zimbabwe to South Africa soon after completing Grade 7 since this is associated with lower socio-economic status such as returning home to households with traditional huts as their main houses or without a plough, cattle or both.

- Zaka and Chipinge district are some of the districts that should be targeted in efforts to control labor migration to South Africa.

- There is a need for further studies involving larger samples to confirm the association found by this study between labor migration to South Africa and poverty since some people who migrate to South Africa expect their socio-economic lives to improve overnight.

\section{References}

Chagonda, T. (2010). Dollarization of the Zimbabwean economy: cure or curse? The case of the teaching and banking sectors. Conference on the renaissance of African economies, Dar as Salaam, Codesria, 20-21.

Creswell, J.W. (2011). Research design: qualitative, quantitative, and mixed methods approach, (2 $2^{\text {nd }}$ ed). Thousand Oaks, CA: Sage.

Crush, J. (2002). Zimbabweans who move: Perspectives on international migration in Zimbabwe. SAMP Migration Policy Series, 25.

Crush, J. \& Tevera, D. (2010). Zimbabwe's Exodus: crisis, migration, survival. Cape Town: Idasa or Ottawa: IDRC.

Hungwe, C. (2012). The migration experience and multiple identities of Zimbabwean migrants in South Africa, Online Journal of Social Sciences Research, 1(5), 132-138.

Iredale, R. Guo, F. \& Rozario, S. (2003). Return migration in the Asia Pacific. Cheltenham: Edward Elgar Publishing Limited.

Kiwanuka, M. \& Monson, T. (2009). Zimbabwean migration into Southern Africa: New trends and responses. Forced Migration Studies Program University of the Witwatersrand.

Lefko-Everett, K. (2004). Botswana's changing migration patterns. Migration Information Source.

Makina, D. (2012). Determinants of return migration intentions: Evidence from Zimbabwean Migrants, living in South Africa, Development Southern Africa, 29(3), 365-378.

Manamere, K. T. (2014). Majoni Joni - Wayward criminals or a good catch? Labor migrants, masculinity \& marriage in rural southeastern Zimbabwe. African Diaspora, 7, 89-113.

Mandiyanike, D. (2014). Zimbabwe's return migrants - before and after challenges. SAMP Policy Brief, 29. 


\section{Journal of Social and Development Sciences (ISSN 2221-1152)}

Vol. 9, No. 4, pp. 26-35, December 2018

Massey, D. S., Arango, J., Hugo, J., Kouaouci, G., Pellegrino, A. \& Taylor, J. E. (1993). Theories of international migration: a review and appraisal. Population and Development Review, 19(3), 431-466.

Mlambo, A. \& Raftopoulos, B. (2010). The regional dimensions of Zimbabwe's multi-layered crisis: an analysis. Election processes, liberation movements and democratic change in Africa conference.

Murisa, T. (2010). Social development in Zimbabwe. Discussion paper prepared for the Development Foundation for Zimbabwe.

Muzondidya, J. (2008). Majoni Joni: Survival strategies among Zimbabwean migrants in South Africa. Paper presented at the International Conference on the Political Economies of Displacement in Zimbabwe, Wits University, 9-11.

New Zimbabwe. (15 April 2015). SA: one Zimbabwean killed 800 displaced.

Pasura, D. M. (2008). A Fractured Diaspora: Strategies and Identities among Zimbabweans in Britain.

Unpublished PhD thesis, University of Warwick.

Roman, M. \& Goschin, Z. (2014). Return migration in an economic crisis context: a survey on Romanian healthcare professional.

Southern Eye. (6 May 2015). Companies retrench over 200,000 workers.

UNDP. (2010). The potential contribution of the Zimbabwe diaspora to economic recovery. Comprehensive economic recovery in Zimbabwe. Working Paper Series, 11.

Yabiku, S. T., Agadjanian, V. \& Sevoyan, A. (2010). Husbands' labor migration and wives' autonomy. Population Studies, 64(3), 293-306.

Zimbabwe Youth Council. (2014). Harmful Cultural and Social Practices Affecting Children: Our Collective Responsibility. 